\title{
A Review of Light Shelf Designs for Daylit Environments
}

\author{
Antonis Kontadakis ${ }^{1, *}$, Aris Tsangrassoulis ${ }^{1}$, Lambros Doulos ${ }^{1,2,3}$ (DD and Stelios Zerefos ${ }^{3}$ \\ 1 Department of Architecture, University of Thessaly, Pedion Areos, 38334 Volos, Greece; \\ atsagras@arch.uth.gr (A.T.); ldoulos@mail.ntua.gr (L.D.) \\ 2 Lighting Lab, National Technical University of Athens, Heroon Politechniou, 9, 15780 Athens, Greece \\ 3 School of Applied Arts, Hellenic Open University, Parodos Aristotelous, 18, 26335 Patras, Greece; \\ zerefos@eap.gr \\ * Correspondence: kontadakis@uth.gr; Tel.: +30-2421-074314
}

Received: 23 November 2017; Accepted: 24 December 2017; Published: 29 December 2017

\begin{abstract}
Light shelves have been discussed in numerous studies as suitable solutions for controlling daylight in side-lit spaces. It is a system that can be easily modified, offering a range of design solutions. It can be easily mounted on the exterior and/or the interior of a vertical opening, it can come in various shapes from static flat forms to curved reflective surfaces, or it can even be actively controlled. A light shelf can offer shading and at the same time can redirect a significant part of the incoming light flux towards the ceiling improving daylight uniformity. Due to the aforesaid functions, light shelves are among the most popular system design solutions when it comes to daylight exploitation. The purpose of this paper is twofold. Firstly, to present the main research findings in relation to light shelves as daylighting systems and secondly to analyze the results, trying to establish a common basis for some efficient and practical design rules. The present paper is a review of the research realized in the last three decades concerning these systems together with their associated implications in a building's daylight performance as well as in its energy balance in a few cases. In addition, the critical review of their design principles is included, which makes the presented information useful for design teams trying to select the optimal available system for any specific project.
\end{abstract}

Keywords: light shelf; innovative daylighting systems; daylighting devices; shading devices; sunlight redirection

\section{Introduction}

Over the last decades, energy and environmental issues have led to increased energy efficiency and improved indoor lighting quality in building design. Yet, despite technological advances in lighting, it has not been possible to match the quality of the illumination produced by daylight. Daylight is preferred by users because of its psychological and physiological effects. These effects are well documented, covering an area from improved health, well-being and productivity for the users, to significant building energy savings [1-5]. Lighting control systems can reduce energy use from electricity by $20 \%$ or even up to $60 \%$ in certain conditions [6-8]. A side benefit to proper daylighting are the reduced costs for cooling, as the amount of heat generated by the lighting system is also reduced [9].

The use of daylighting systems, in an effort to increase core daylight illuminance, may reduce lighting energy consumption, but careful design is needed in order to avoid possible increases in cooling loads especially in cooling-dominated locations [10]. Thus, the main task of the design teams is to balance antagonistic phenomena, in an effort to maximize the users' thermal and visual comfort. 
For example, simultaneous reduction of solar gains and the provision of sufficient daylight levels with an improved uniformity is a typical problem that should be tackled during the initial design phase.

Daylight can be delivered into a building with conventional techniques; windows, clerestories, etc. are common examples of side-lighting applications which have the disadvantage of only effectively illuminating areas that are located near them. The area benefiting most is called a daylit or perimeter area and is affected mainly by window placement and dimensions [11-14]. Consequently, daylight distribution is not uniform in deep spaces, even when a fully glazed façade is used. In these cases, daylight alone cannot adequately illuminate the space without additional support from artificial lighting, especially in areas away from the facade. One way of addressing the problem is by integrating systems to the aperture that are capable of collecting and distributing daylight into the space, and if possible, enhancing the indoor daylight levels at the area further most from the openings. Thus, incoming solar radiation can be controlled by either using shading systems, such as overhangs, solar screens, venetian blinds, rollers and louvers, etc., where problems associated with solar gains and potential glare can be moderated $[15,16]$ or by adopting daylighting systems whose primary function is to redirect a significant part of the incoming light flux towards the ceiling. Thus, a more balanced distribution of daylight accompanied by a reduction of excessive illuminance levels near the windows can be achieved [17-20].

There have been substantial research efforts placed on designing daylighting systems, in order to protect occupants from direct solar glare, but also to improve daylight distribution. The latter can lead to a reduction in electrical consumption for lighting [21-23]. Attempts to classify different daylighting systems have been presented in several articles and review papers [24-28]. Light shelves represent one of the most popular design choices in contemporary buildings and are often suggested in literature as effective devices that can improve the lighting quality of a space and offer energy savings especially when daylight controls are used. Light shelves are possibly the simplest among daylighting systems; a horizontal/inclined surface which is placed on a window above eye level, either internally or externally, is capable of controlling and redistributing incoming daylight through reflection on its upper surface. Due to its position in relation to the opening, it divides the window into two parts; an upper part (clerestory) which can be considered as daylight provider and a lower one (view) window. Therefore, it can act either as a shading device which blocks excessive sunlight impinging on the working surface and if installed externally, it can reduce solar gains or as a daylighting device, bouncing off reflected sunlight usually onto the ceiling plane and pushing daylight deeper into the space. Till today, many light shelf designs have been proposed. Static or sun-tracking, using specular reflection or refraction, flat or curved; their performance is mainly examined in relation to the indoor lighting levels achieved.

The main task of this paper is the systematic review of light shelves as presented in the bibliography, by examining the factors that affect their performance design aspects that need to be considered when installing a light shelf; the influence of weather and sky conditions and, we discuss several light shelf system configurations by synthesizing their content and summarizing the results and conclusions. The purpose of the paper is twofold. Firstly, to present the main research findings in relation to the light shelves as daylighting systems, and secondly, to analyze the results, trying to establish a common basis for some efficient and practical design rules.

\section{Overview}

Although the use of mirrors as a means to redirect sunlight has been known since antiquity (for example the specular characteristics of the concave side of shields used by Archimides in 212 BC to burn the sails of the Roman fleet, or the use of mirrors to reflect sunlight at the theater stage) it was Anthemius of Tralles and Isidore of Miletus who designed an early type of the light shelf for Hagia Sophia in Constantinople (present day Istanbul, Turkey) in the 6th century AD. In the initial design, Anthemius used reflective window sills, which were located around the dome so that sunlight was reflected to the interior surface of the dome in an effort to increase its brightness [29,30]. A schematic representation of the system is presented in the following Figure 1. 


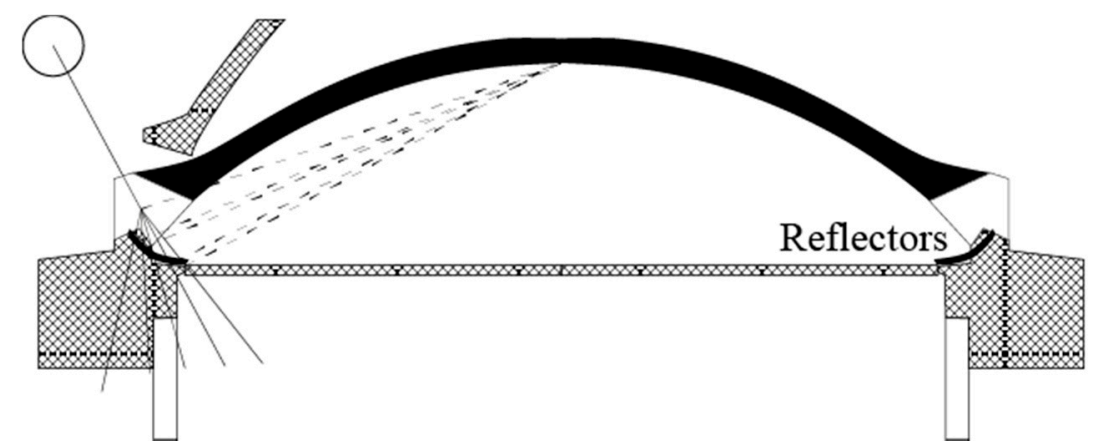

Figure 1. Schematic representation of the parapet of Hagia Sophia based on Anthemius's reflector superimposed over the cross-section of the original dome and parapet presented to [29].

Although in late nineteenth century reflectors were in production to increase indoor illuminances like the Tageslicht reflector form W. Hanifch and Co. which was presented in Berlin trade fair during 1889, illustrated in Figure 2.

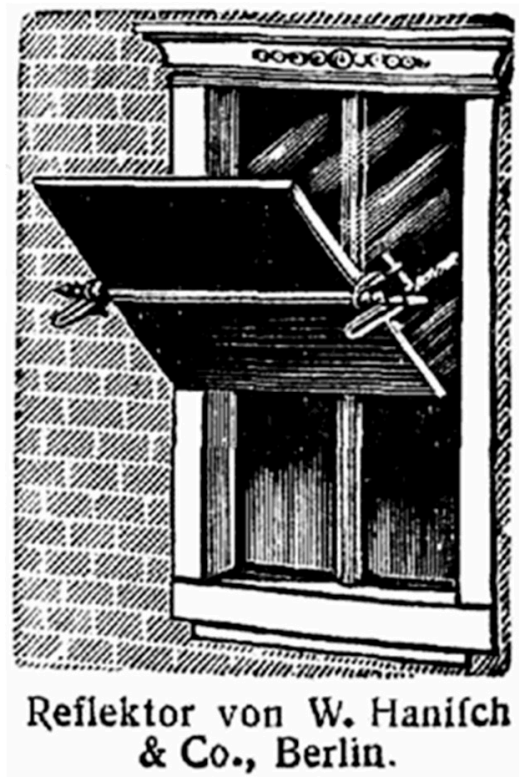

Figure 2. Daylight reflector by W. Hanifch and Co. [31].

It is not quite clear when the term "light shelf" started to be used. An early study for the use of light shelves in hospitals was carried out by Hopkinson during the 1950s [32]. Since the light shelf represents one of the simplest systems which reduces solar gains and redistributes daylight into the building interior, a large number of papers have been written in an effort to examine all related parameters affecting their performance. Focused research on the performance of light shelves begun during the 1980s. Although the light shelf's effect on a building's energy balance (especially in cooling loads during summer) is important, in this review, the term "performance" is related to the resulting luminance and illuminance distribution on the surfaces of the space associated with it. This performance varies according to the prevailing sky conditions, as light shelves control diffuse and direct illuminance differently according to the shelf's geometry and the material used in its upper surface. External light shelves offer daylight redirection together with shading of the lower window while the interior ones can minimize the sun-patch area on a working surface, especially in low altitude angles, thus, improving luminance distribution. It is therefore evident that their depth can significantly affect illuminance levels. An example is presented in the following Figure 3. 

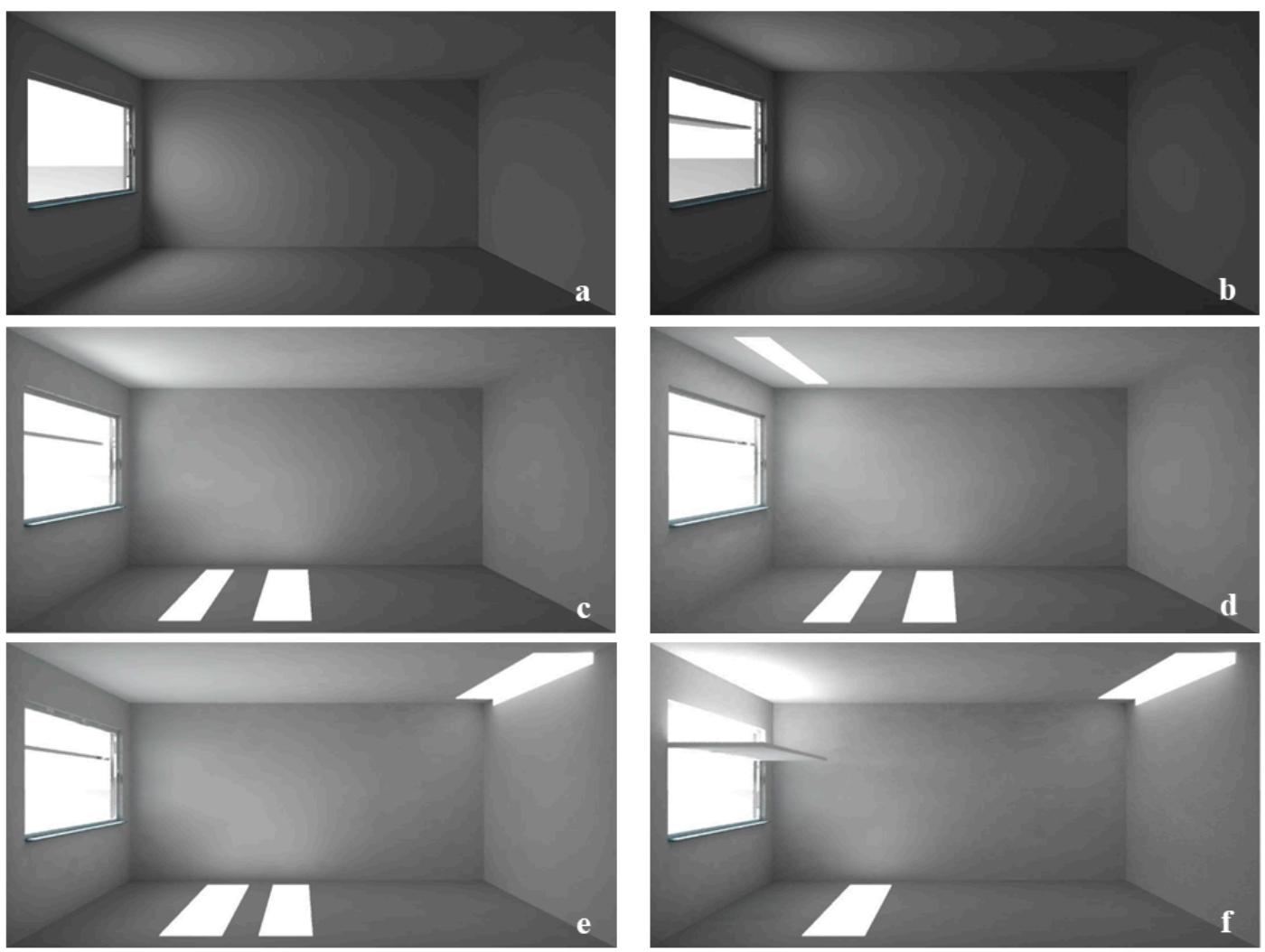

Figure 3. Various interior radiance renderings of a south oriented room with dimensions $4 \times 6 \times 3 \mathrm{~m}$ and a window to floor ratio equal to $20 \%$ equipped with: (a) No light shelf, under overcast sky; (b) Perfectly diffuse external horizontal light shelf with $0.5 \mathrm{~m}$ depth (reflectance 0.8 ), under overcast sky; (c) Perfectly diffuse external horizontal light shelf with $0.5 \mathrm{~m}$ depth, under clear sky conditions, sun's elevation $37.8^{\circ}$; (d) Like; (c) but with mirror external horizontal light shelf; (e) Similar to; (d) with the external inclined upwards by $15^{\circ}$; (f) Similar $€$; (e) with a perfectly diffuse internal light shelf (depth $1.2 \mathrm{~m}$ ).

Thus, the parameters identified in this review, affecting light shelf's performance are the following:

(a) Geometrical (width, length, mounting height, tilt angle and shape).

(b) Reflectance type (specular or diffuse).

(c) Material type (metal perforated or not, transparent).

(d) Position adjustment (rotation, operation).

(e) Building data (room dimensions including ceiling shape).

(f) Climatic conditions.

It must be mentioned at this point that direct comparison of the performance of various light shelf designs is quite difficult as there is no analysis on component level in the bibliography (except anidolic systems). The existence of light shelf metrics, could give an indication of their daylight implications. Today, most of building standards are oriented to the performance based approach, setting specific targets for the whole building. This in turn, reduced the usefulness of the light shelf metrics making their comparison in the initial design phase cumbersome. A light shelf metric could be the estimation of bidirectional transmittance distribution function which represents the variation of optical properties with the angle of incidence. In all papers examined, light shelf's performance was evaluated according to the illuminance levels on the working surface of a room or the luminance distribution on its surfaces. Since room dimensions used by various research teams varied widely, optimized designs varied as well. 
Therefore, the criteria used for the performance evaluation of a light shelf, which are common among daylighting systems, are the following:

1. An increase in illuminance especially in non-daylit areas.

2. An increase in uniformity.

3. The improvement of visual comfort.

4. The provision of sufficient shading.

Light shelves can be categorized according to their geometrical form. Therefore, in the present paper, research results are presented for (a) horizontal, (b) flat tilted, (c) curved and finally, (d) active light shelves.

\subsection{Performance Analysis of Static Horizontal Light Shelves}

This is the simplest form of a light shelf. The types of light shelves that have been examined are horizontal and tilted with mirrored/diffuse upper reflecting surfaces. Selkowitz, et al. [33], suggested that under sunny skies, light shelves are effective at increasing light levels at the back of the space compared to standard clear glass windows and concluded that in general, simple light shelf designs provide improvements in daylight penetration. They suggested that maximum exterior light shelf depth $\left(d_{\text {ext lightshelf,max }}\right)$ should be less than 1.5 times the height of the clerestory window $\left(h_{\text {clerestory }}\right)$ above it.

$$
d_{\text {ext lightshelf,max }} \leq 1.5 \times h_{\text {clerestory }}
$$

According to Place et al. [34] the depth of the exterior horizontal light shelf should be 1.25-1.5 times the height of the clerestory window for South oriented façades (for $20^{\circ}$ either side of South) and $1.5-2$ times the clerestory height for façade azimuth angles greater than $20^{\circ}$ and lower than $160^{\circ}$ (azimuth from North $0^{\circ}$, clockwise).

Littlefair [35] continued his previous work simulating the behavior of light shelves. His findings show an increase in daylight uniformity but without significantly increasing illuminances at the back of the room. Light shelves performed better when there was an external obstruction increasing core illuminance values by around $15 \%$. This analysis provided some information on optimum light shelf dimensions. The interior depth $\left(d_{\text {int lightshelf }}\right)$ should be equal to the height of the clerestory window above it $\left(h_{\text {clerestory }}\right)$, while external depth $\left(d_{\text {ext lightshelf }}\right)$ should be smaller than the difference between the distances of the light shelf's height from the floor $\left(h_{\text {lightshelf }}\right)$ and the working plane $\left(h_{\text {work-plane }}\right)$. Upper light shelf reflectance should be as high as possible while its performance increases when it is used in high ceiling spaces, as illustrated in Figure 4.

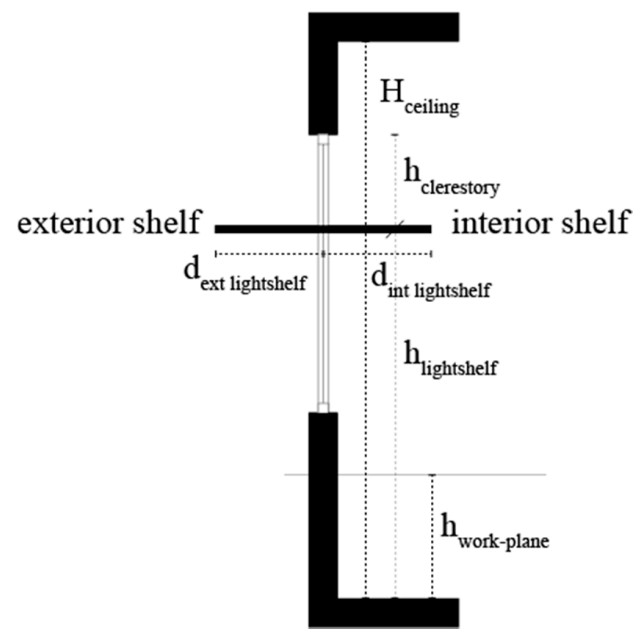

Figure 4. Cross-section of a side-lighted space with an extended light shelf (internal and external) and main dimension parameters. 


$$
\begin{gathered}
d_{\text {int lightshelf }}=h_{\text {clerestory }} \\
d_{\text {ext lightshelf }} \leq h_{\text {lightshelf }}-h_{\text {work-plane }}
\end{gathered}
$$

Abdulmohsen et al. [36] investigated the impact of the light shelf depth on daylight working surface illuminance using internal, external and combined light shelves. Upper light shelf surface reflectance was $80 \%$ and light shelves depth varied from 0 to $3.5 \mathrm{~m}$ for the external and from 0 to $3 \mathrm{~m}$ for the internal ones, mounted on the window $2 \mathrm{~m}$ above the floor. The evaluations were based on scale models for daylighting measurements and simulation models for energy estimations in Texas, USA. The scale model represented a South oriented open plan office space with dimensions of $9 \times 9 \mathrm{~m}$ and a height of $3.5 \mathrm{~m}$ with Window-to-wall Ratio of $100 \%$. The light shelf was designed to provide adequate shading to the lower view window and of course, to reflect light deep into the space through the clerestory window above the shelf. Different light shelf depths were evaluated and compared against overhangs of variable sizes corresponding to lengths of $1.2 \mathrm{~m}, 2.5 \mathrm{~m}$ and $3.65 \mathrm{~m}$. In terms of illuminance levels, uniformity and glare discomfort, the results showed that combined (internal and external) light shelf systems perform more effectively, considerably improving uniformity. Among the cases examined, an exterior light shelf with a depth of two to three times the height of the view window and an interior light shelf with a depth of two to three times the height of the daylight window performed in the best way. However, as the authors stated, the results corresponded to the data collected for a low solar altitude angle $\left(30^{\circ}\right)$ and this explains the large size of the shelfs.

Littlefair et al. [25] tested an internal light shelf that was $1 \mathrm{~m}$ deep at a height of $2.08 \mathrm{~m}$ from the floor, mounted in a mockup office facing slightly West of due South (Latitude: $53.35^{\circ} \mathrm{N}$ ). The office space was $3 \times 9 \mathrm{~m}$ with ceiling height of $2.7 \mathrm{~m}$. Because the system managed to reduce light levels more at the front of the room than at the back, uniformity increased under all conditions but with smaller improvements occurring during overcast sky conditions. Compared with the reference case (conventional glazing) findings from measurements showed a reduction in daylight levels ranging from $10 \%$ to $20 \%$. As a general conclusion they suggested that fixed systems can only increase core illuminances under certain well-defined conditions; when the sun shines directly onto the window and their performance could be increased if a movable system that can be adjusted to work more effectively is adopted. It seems that a large increase in core daylight illuminance was not feasible and therefore, in UK, these daylighting systems should be considered as shading devices.

Soler and Oteiza $[37,38]$ used two South oriented scale models with rectangular openings to examine the efficiency of a highly reflective (91\%) light shelf, in Madrid, Spain (Latitude: $40.41^{\circ}$ ). The models represented spaces with dimensions of $6 \times 6 \mathrm{~m}$ with a ceiling height of $2.8 \mathrm{~m}$ and a Window-to-wall Ratio of 50\%. One was equipped with the light shelf and the other was left free of obstruction to act as the reference case. Measurements of mean hourly illuminances were obtained during a period of one year from both models. The objective was to show the dependence of solar elevation and solar azimuth on daylighting efficacy. This was defined as the ratio of the mean hourly illuminances obtained by the model equipped with the light shelf and the reference model respectively. As a shading device, the light shelf was designed with a vertical shading angle of $50^{\circ}$. The light shelf provided higher uniformity than the reference model. Measurements show that the efficacy of the system increases together with the solar elevation up to a point and then decreases. Further increase in the solar elevation resulted in a decrease of the light shelf's performance. The maximum values of daylight efficacy $(>1)$ are only obtained on clear days, and approximately between 110th and 270th day of the year. This implies that exterior light shelves have a difficulty to treat lower sun positions.

In a similar study, Carlos, and Soler [39] compared the daylighting performance of two light shelf configurations that had both internal and external parts against overhangs. Four scale models with South facing apertures were constructed using the same space dimensions as [38,39]. The first was equipped with a white opaque metacrilate light shelf, the second with a mirror light shelf, the third had an overhang, while the last one was left without a shelf as a reference case. Illuminance 
measurements took place in Madrid, Spain for a period of one year. The light shelves and the overhang were designed to provide the same shading effect (vertical shading angle of $50^{\circ}$ ) as shown in Figure 5 .

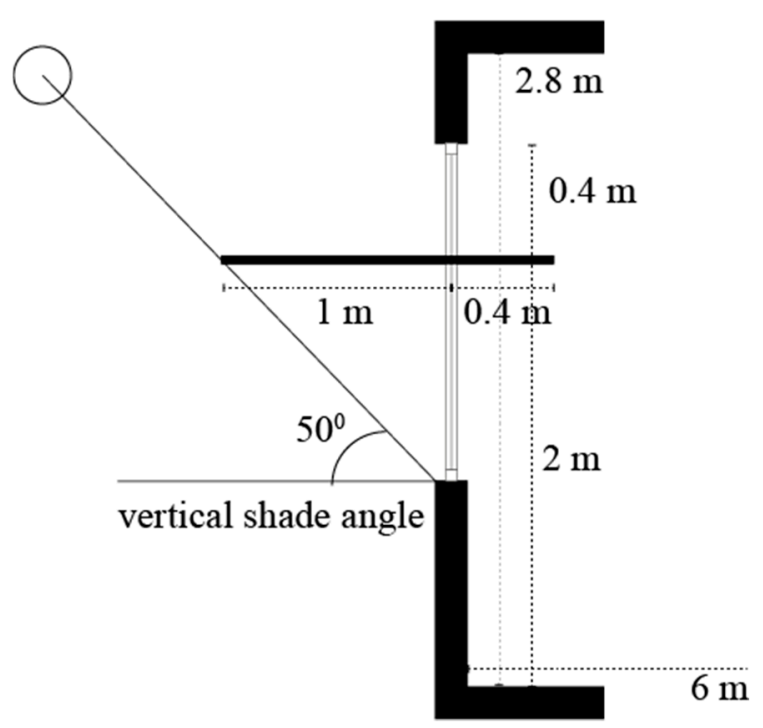

Figure 5. Light shelf dimensions and vertical shade angle as examined in [39].

Findings of that study showed that light shelves, by redirecting light into the interior, performed better than a classic overhang by 10-25\% in terms of illuminance levels inside the space. The metacrilate light shelf is more efficient than the mirror one, during the central months of the year and for the hours from 08:30 to 11:30 showing improvements ranging from 10\% to 35\%. The opposite happens at the beginning and at the end of the year. These results emphasize the importance of the light shelf's upper surface reflectance.

Berardi and Anaraki [40] assessed the benefits of light shelves, calculating useful daylight illuminances (UDI) in office buildings by conducting annual simulations taking different Window-to-wall Ratios, window shapes, façade orientations and external obstructing elements into consideration. The South oriented space had dimensions of $10 \times 15 \mathrm{~m}$ and a ceiling height of $3 \mathrm{~m}$ and was located in Toronto, Canada (Latitude: $43.65^{\circ} \mathrm{N}$ ). The optimal length and depth of the shelves was calculated based on the following parameters: the window head height, the sill height, the height of the light shelf, the wall thickness and the sun position (solar altitude and solar azimuth). The results showed that in the context of analysis, light shelves increased the useful daylight illuminance values mainly in the first $6 \mathrm{~m}$ from the windows and provided a more uniform distribution of daylight. This study indicated that narrow full-height windows provide better daylighting compared to shorter but wider windows and, light shelves have no benefits when applied to windows not facing South. Furthermore, the study showed that regardless of the window geometry, light shelves enhance daylighting especially in the front zone and especially for South facades. The maximum level of UDI for cases without light shelves occurred at $3 \mathrm{~m}, 4 \mathrm{~m}, 5.5 \mathrm{~m}$ and $6 \mathrm{~m}$ away from the windows, when window-to-wall Ratio is $25 \%, 35 \%, 45 \%$ and $55 \%$, respectively. The presence of the light shelf decreases a bit the above-mentioned distances to $2.5 \mathrm{~m}, 3.5 \mathrm{~m}, 4 \mathrm{~m}$ and $5.5 \mathrm{~m}$. The final design of the light shelves had a height of $2.25 \mathrm{~m}$ from the floor with the reflectance set at $80 \%$.

Ochoa and Capeluto [41] performed a daylight analysis of a deep meeting room equipped with a light shelf using radiance simulations. The room is located in Haifa (Latitude: $32.5^{\circ} \mathrm{N}$ ). Three systems have been examined: a single window without any external protection, a horizontal light shelf and an anidolic concentrator. The dimensions of the simulated light shelf are presented in Figure 6. 


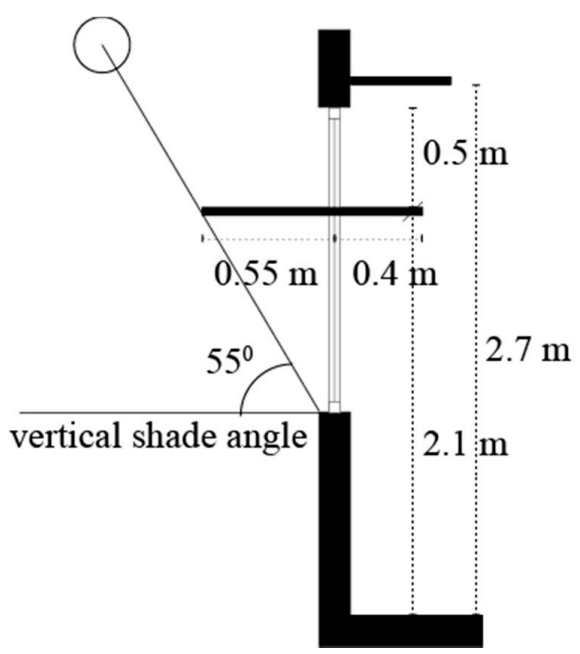

Figure 6. Examined light shelf configuration with the main dimensions [41].

The results indicate that the light shelf provides a safer approach to the problem of daylight penetration, reducing contrast between areas near the window and those at the back of the room, by sacrificing illuminance levels. The illuminance values beyond the daylight zone that exceeded $3001 x$ was 1.5-2 times higher when compared with the reference case. In addition, the light shelf had maximum efficiency when the sun shone directly over it, while its effectiveness is reduced at distances more than 6-7 $\mathrm{m}$ from the window. The anidolic system was found to increase lighting levels throughout the room for all orientations.

Joarder et al. [42] performed a series of daylight simulations in Dhaka, Bangladesh (Latitude: $23.8^{\circ}$ ) of horizontal combined (exterior and interior) light shelves with a depth of $0.5 \mathrm{~m}$ in both directions and an upper surface diffuse reflectance equal to $88 \%$. The analysis parameter was the light self's height from the floor under overcast sky conditions. Figure 7 illustrates the cases that were taken into consideration.

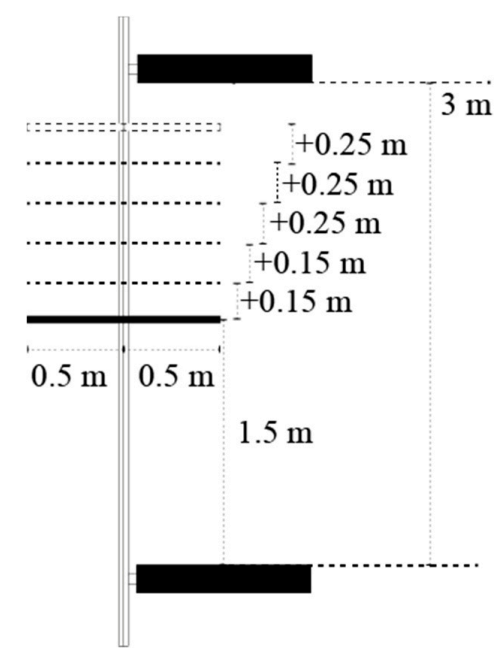

Figure 7. Extended lightshelf with equal depths for the internal and external shelf $(0.5 \mathrm{~m})$ and variable heights that were examined [42].

Again, as noted in other studies, the average illumination is higher in the case without the use of a light shelf, while the uniformity is better. The daylight levels calculated for the case w/o the light shelf installed were on the average $650 \mathrm{~lx}$, but with uneven distribution. For the cases with the light shelves the max avg. value (478 lx) was observed for the highest configuration $(2.75 \mathrm{~m}$ above 
the floor level), and the min. at $2 \mathrm{~m}$ height. In the deeper areas, the effect of light shelf height on the illumination levels was not as significant due to overcast sky conditions. However, brightest interior ceilings were recorded for a light shelf at a height of $2 \mathrm{~m}$ and darkest for a light shelf at a height of $2.5 \mathrm{~m}$. The results indicate that light shelf with a height of $2 \mathrm{~m}$ from the floor level together with $3 \mathrm{~m}$ high ceilings performed better than other alternatives including a reference case, where no light shelf was present. In addition, there was a significant increase of the work-plane illuminance values ranging between $300-9001 x$ by $60 \%$ compared with the unshaded case.

A study conducted by $\mathrm{Hu}$ et al. [43] evaluated the performance of various interior light shelves initially using scale models in Raleigh, North Carolina, USA (Latitude: $35.7^{\circ} \mathrm{N}$ ). The data collected from the measurements were used to validate simulations performed on yearly basis using DAYSIM. The parameters examined were the depth of the light shelf, the ceiling height and, interior partitions typical of North American office building settings, in a multi-storey office building. The examined interior lengths of the shelf ranged from $0.6 \mathrm{~m}$ to $3.6 \mathrm{~m}$ with a step of $0.6 \mathrm{~m}$ while the height and interior kept the same. In the same manner the ceiling height was studied varying from $2.75 \mathrm{~m}$ to $3.65 \mathrm{~m}$ with $0.3 \mathrm{~m}$ step and the interior light shelf was set at $0.6 \mathrm{~m}$. The results revealed that although light shelves generally enhance daylight in areas away from the opening, their performance is dependent on the clerestory area, and the ceiling height. Adding partitions that are either parallel or perpendicular to the South-facing window results in a major decrease of the illuminance values especially in areas away from the window. Among the six cases, the light shelf with $1.2 \mathrm{~m}$ depth performed better when compared with the alternatives, but an interior depth of $1.85 \mathrm{~m}$ appeared to be the optimal solution providing more shading by blocking direct sunlight. The increase of the ceiling illuminance resulted in an increase of daylight penetration deeper inside the space.

Lim and Ahmad [44] assessed the daylight performance of several interior light shelf configurations using side by side measurements of illuminance in two scale models which represent spaces $8.4 \mathrm{~m}$ long, $8.4 \mathrm{~m}$ wide and $2.7 \mathrm{~m}$ high in Johor, Malaysia (Latitude: $1.33^{\circ} \mathrm{N}$ ) with a window-to-wall Ratio of $70.4 \%$ and glazing transmittances of $25 \%, 50 \%$, and $75 \%$. Single, double and triple light shelves made of aluminum (reflectance $51.29 \%$ ) were evaluated with a depth of $0.3 \mathrm{~m}$ and $0.6 \mathrm{~m}$ (reflectance $51.29 \%$ ) and variable clerestory heights $(0.3 \mathrm{~m}$ and $0.45 \mathrm{~m}$ ) under various sky conditions, as illustrated in Figure 8. The internal light shelves were able to improve uniformity by as much as 30-90\% under intermediate sky without direct sunlight when compared with the base case (without light shelf). The results proved that internal light shelves were not only effective to reduce the extremely high illuminances at the area near to window, but were also able to increase illuminances at the deeper area of the room and this occurs even for overcast conditions. According to the findings, the most effective performance was achieved in low zenithal angles. These results are contradictory to the results presented by Littlefair [36] whose main findings suggested a reduction in illuminance levels under overcast sky conditions.

Kurtay and Esen [45] proposed a methodology for determining the best light shelf arrangement using the simulation of a typical office unit for six latitudes for three different office heights using CIE Standard overcast sky. Indoor illuminance values were correlated with various light shelf sizes and positions and as a result, a set of curves were created. These curves (CUN-OKAY) can be used to estimate a proper light shelf for a specific location.

Warrier and Raphael [46] used both illuminance measurements in scale rooms in Chennai, India (Latitude: $13.08^{\circ} \mathrm{N}$ ) and simulations to test the impact of two types of light shelves (specular and diffuse) and their tilt angles on the daylight distribution. Measurements showed that when a horizontal light shelf (aluminum or mirror glass) was used, there was an increase of about $21 \%$ in illuminance levels. Surprisingly, the simulation studies showed that in $30 \%$ of the examined cases, the light shelves increased the illuminance near the window reducing illuminance uniformity.

Lee et al. [47] compared the performance of two light shelves, one mirrored and one using diffused reflection as this was achieved by a combination of various shapes of crystal faces located on the flat upper surface of the light shelf. A South oriented room in Seoul, Korea (Latitude: $37.56^{\circ}$ ) with 
dimensions $4.9 \times 6.6 \times 2.5 \mathrm{~m}$ was used which had $32 \%$ Window-to-wall Ratio. The results indicate that there is a substantial increase in uniformity. This increase was $29.9-34.3 \%$ for the external light shelf and $10.4-13.7 \%$ for the internal, compared to the existing flat mirror-type light shelf. In addition, lighting energy savings can increase by $7.98-13.3 \%$ (external light shelf) and by $1.8-4.4 \%$ (internal light shelf) when compared to the flat mirror light shelf.

Among technical papers so far examined, the work of Moscoso and Matusiak [48] is very interesting since it examines the influence of a light shelf -among other systems- on the aesthetic perception of a small office. Four different daylight systems have been installed in an office room in Trondheim, Norway (Latitude: $63.43^{\circ}$ ) and fifty participants evaluated stereoscopic images rating nine architectural quality attributes under clear and overcast sky conditions. The results under clear sky show an increase on luminance contrast when a light shelf is used giving rise to glare problems and making the room less pleasant than other daylighting systems (such as reflective blinds). After analyzing the results, it seems that the reflective blinds rated highest in nearly all attributes.
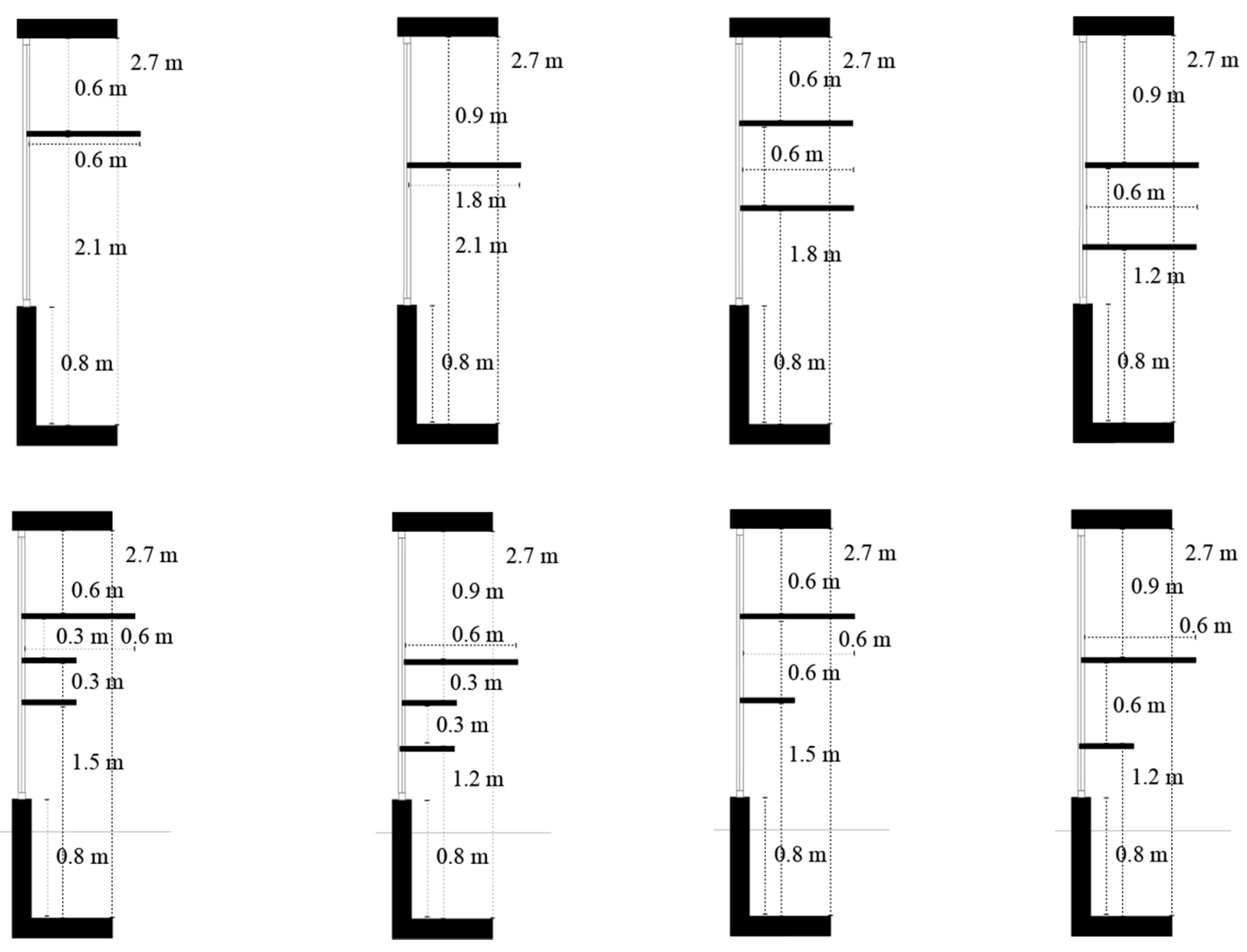

Figure 8. Schematic representation of the cases studies that have been examined in [44].

\subsection{Performance Analysis of Flat Tilted Light Shelves}

Moazzeni and Ghiabaklou [49] examined a number of parameters using simulation: the external light shelf depth varied from $0.3 \mathrm{~m}$ to $1.2 \mathrm{~m}$, the internal shelves width varied from $0 \mathrm{~m}$ to $1 \mathrm{~m}$, while their slope angle was set equal to $0^{\circ}, 5^{\circ}, 10^{\circ}, 20^{\circ}$ and $30^{\circ}$. The educational space was in Tehran, Iran (Latitude: $35.68^{\circ}$ ), with dimensions of $7 \times 8 \mathrm{~m}$, with $3.5 \mathrm{~m}$ ceiling height and a WWR of $50 \%$ and all cardinal orientations were simulated. The results showed that for the south orientation, increased light shelf dimensions result in an increase of the area of the work plane with suitable daylight levels while glare was reduced when compared with the space without the light shelf installed. It seems that horizontal external light shelves are more efficient than those that have a slope angle of $30^{\circ}$. For north orientations, the lack of direct sunlight penetration resulted in a poorer daylight performance 
of the space when a light shelf is installed. As the light shelves' internal and external depth increased, daylight illuminance decreased while their slope angle did not have any significant impact. The results were nearly identical for the east and west orientations. Generally, the increase of the internal and external light shelf dimensions decreased areas that were over-lit, due to improving the shading of the window. The raise of the tilt angle of the shelf caused an increase in direct sunlight penetration which in turn hindered the daylight performance of the space.

Moore [50] suggested that the optimum upward slope angle of a light shelf painted white can be calculated using the equation for south oriented spaces:

$$
\text { Slope Angle }=40^{\circ}-(\text { Latitude } / 2)
$$

and $15^{\circ}$ for east and west orientation.

Meresi [51] studied a south oriented typical classroom in Athens, Greece (Latitude: $37.98^{\circ}$ ) using simulation. The model used for the simulation was validated by comparing daylight factors estimated by simulation and measurements from an actual classroom. The façade system consists of a light shelf and semi-transparent movable external blinds. The results indicate that the best case in terms of increased daylight illuminance levels and glare reduction is the one with the external light shelf installed at $2 \mathrm{~m}$ from the floor, and a depth of $0.80 \mathrm{~m} \pm 0.20 \mathrm{~m}$ and a tilt angle between $10^{\circ}$ and $20^{\circ}$ with a reflectance equal to $90 \%$. The use of a reflective light shelf to reduce glare problems and redistribute daylight in an educational open-plan studio space was investigated by Al-Sallal [52]. In this research, several tilt angles of a light shelf installed on the north façade were examined along with other design parameters, such as the height of the light shelf and the slope of the ceiling. The average value of the daylight factor for the base case was $30.28 \%$. For the sloped ceiling case the avg. value for the daylight factor was $29.24 \%$ and the daylighting levels in most points lower than $1 \mathrm{~m}$ in the studio were less than 2000 lx. Though sloping the ceiling did not generally make much difference, more even distribution of daylight factor levels across the height of the space was observed. The results indicate that $5^{\circ}$ sloped ceiling together with a slope angle for a light shelf equal to $60^{\circ}$, helped to reduce the illuminance differences between the ceiling and the back wall.

\subsection{Performance Analysis of Curved Light Shelves}

We consider as advanced light shelves all shelves that either guide direct sunlight in the interior of a space or concentrate and redistribute diffuse daylight. In almost all cases highly reflective surfaces when used with static shelves have a more complicated geometrical form (i.e., anidolic), while the cases of dynamic shelves (i.e., sun tracking light shelves) need a control strategy to adjust their position in relation to the clerestory window. Thus, their operation is based on their rotation according either to the sun's position and aiming point on the ceiling [53] or to the lighting energy achieved [54].

In May 1996, Lee et al. [55] proposed a highly reflective curved light shelf with a small inlet aperture capable of redirecting sunlight into depths of $9 \mathrm{~m}$ from the window wall. Scale model results proved that illuminance uniformity improved more than a typical diffusing hemisphere skylight. The system was installed in real scale where a number of visitors were polled for their opinion on visual comfort issues. The results were satisfactory.

Beltran et al. [56] tested a number of light-shelf designs together with light pipes. This work was a continuation of a previous research [57]. In total, four systems were tested in Los Angeles (Latitude: $34^{\circ} \mathrm{N}$ ) for south and east/west orientations. The light shelf designs that were tested are presented in Figure 9. The systems were designed using ray-tracing techniques and daylight measurements in scale models and then their behavior was simulated using the DOE 2.1E building energy analysis software. The room used for the study had a clerestory window of $0.5 \mathrm{~m}$ height while the room itself was $3 \mathrm{~m}$ high. Four light shelf designs were used: (a) a horizontal static exterior and interior (depth $1.1 \mathrm{~m}$ in total) whose upper surface had been painted white, (b) a single level curved light shelf with side reflectors whose surfaces had been covered with a specular reflector 
film, (c) a bi-level and, (d) a multi-level light shelf. The curved (b, c, d) configurations consisted of a segmented surface to redirect sunlight with changing solar altitudes. The inclination of each segment was computed by considering window orientation and site latitude, to ensure an optimal angle for redirection into the space. These segments were coated with a highly reflective thin film (reflectance $88 \%$ ) that could produce two types of reflection: specular and narrow spread. The aperture area for the single level light shelf was $2.8 \%$ of the floor area and a working surface illuminance over $200 \mathrm{~lx}$ was achieved throughout a year from 10:30 to 13:30 at a distance of $8.4 \mathrm{~m}$ from the window under clear sky conditions. The bi-level light shelf has an aperture area more than twice that of the single level and achieves even higher illuminance levels than the base case. Overall, light shelf designs can increase interior daylight levels in a zone of between 4.6 and $9.1 \mathrm{~m}$ away from the window wall under clear skies with a rather small aperture area. Follow up studies were presented, further developing the aforesaid prototypes to improve daylighting performance at more oblique solar angles to the window $[58,59]$.
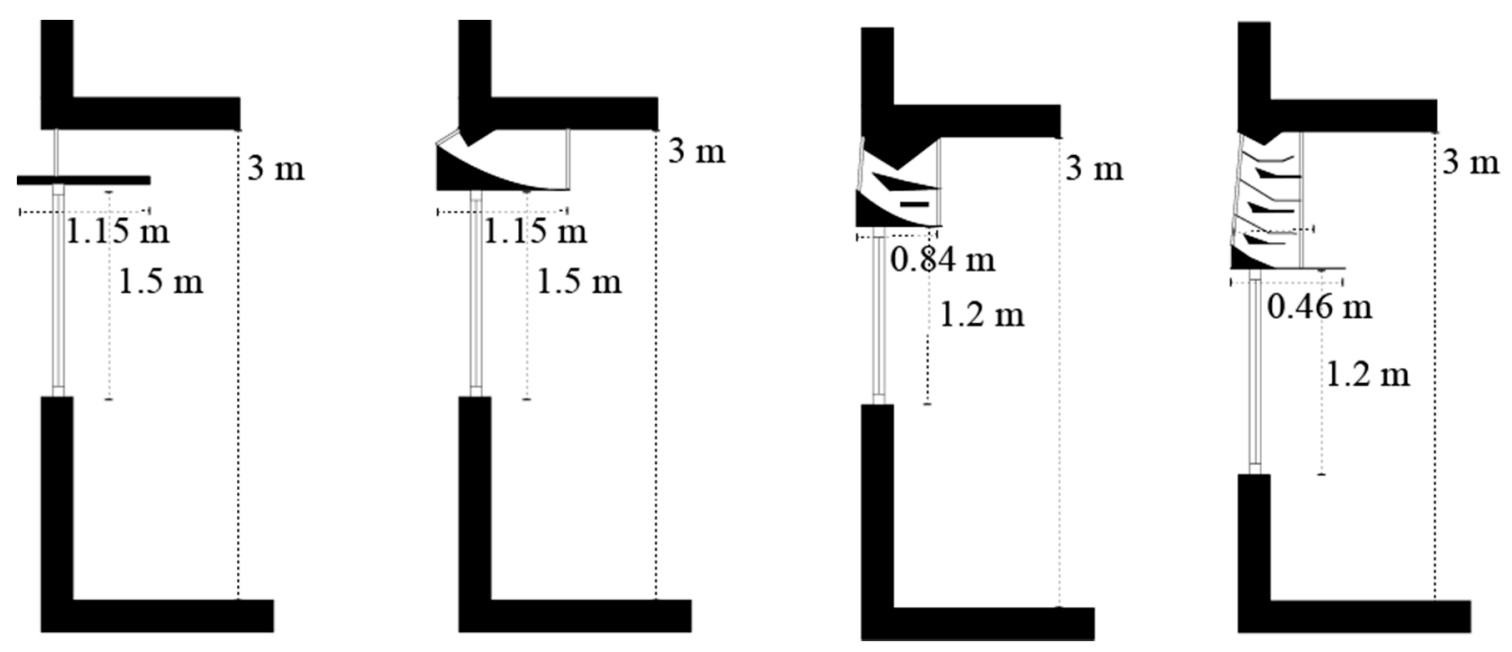

Figure 9. Schematic representation of the cases examined in [56].

Lee et al. [60] proposed perforated light shelves aiming at minimizing the effect of wind pressure when they are installed in high rise buildings. An actual-scale testbed was used to evaluate the performance in terms of lighting energy savings. The perforated light shelf was produced by punching holes of various shapes into the reflectors' surface. The parameters examined were the vent ratio which is defined as the ratio of the perforated area to the entire area of the shelf and the tilt angle of the shelf. The results show that increasing the vent ratio from $29.5 \%$ to $35.3 \%$ there is an increase of lighting energy consumption from $20.6 \%$ to $48.3 \%$ respectively, in comparison with the results from a case with a non-perforated light shelf. The reason for that is the reduced amount of natural light that is brought into the indoor space via reflection due to the perforation of the light shelf. However, lighting energy consumption is reduced when the results of the previously mentioned cases are compared with that from the case without any shelf.

Scartezzini and Gourret [61] presented a performance analysis of three anidolic daylighting systems installed in a $6.55 \mathrm{~m}$ deep space in Lausanne (Latitude: $46.51^{\circ}$ ). One of them was an integrated system as illustrated in Figure 10, which was assessed using simulations for two types of ceiling (flat and slanted). In both cases, the system shows an increase in daylight factors in comparison to a reference façade with conventional double glazing. In the deepest part of the room, the increase in daylight factors was 1.4 times the value of the reference case when there was no external obstruction and 1.7 when an urban environment was simulated. 


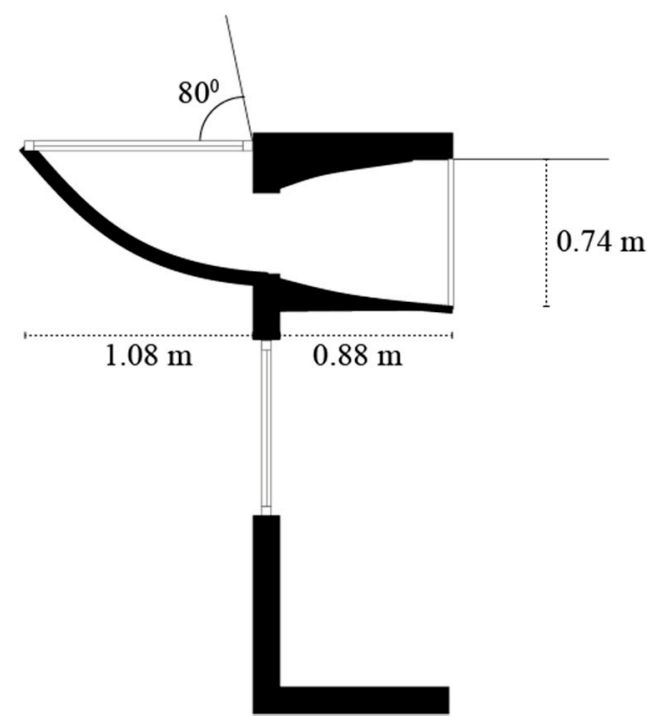

Figure 10. Schematic representation of an anidolic daylighting system as examined in [61].

Another work dealing with the modification of the ceiling geometry is that of Freewan et al. [62]. In this paper, the authors studied the interaction between various ceiling geometries with a light shelf, using experiments with scale models and Radiance simulations in a deep side-lighted space. Various ceiling configurations were tested including curved, chamfered, sloped upward from the window, and sloped downward from the window. The evaluation of the light shelf performance due to modified ceiling geometries is based on the calculation of illuminance levels and the uniformity on the working plane. The scale model used represents a south oriented room in Irbid, Jordan (Latitude: $32.55^{\circ}$ ) with dimensions $6 \times 8 \mathrm{~m}$ with a ceiling height of $3.25 \mathrm{~m}$ and a window-to-wall Ratio of $40 \%$ located). The illuminance levels increased in the rear part of the room by $21-36 \%$ and decreased by $20-55 \%$ in the front when a curved or chamfered ceiling is used. When changing the ceiling surface reflectance type to specular, a further increase in illuminance levels at the back of the room was observed. This increase is $52 \%$ and $30 \%$ for curved and chamfered ceilings respectively in comparison with the illuminance values estimated for a flat ceiling. In addition, the illuminance level at the front of the room was reduced by $27 \%$ and $30 \%$ for curved and chamfered ceilings, respectively. In general, the best ceiling shape in terms of daylight levels and uniformity was curved.

Extending his previous work, Freewan [63] examined in this paper the combination of curved ceilings with a number of curved light shelves (Figure 11). The south oriented room used for the simulations was $8 \times 6 \mathrm{~m}$ with ceiling height $3.25 \mathrm{~m}$ and window-to-wall Ratio of $35.8 \%$. Both external curved and chamfered exterior light shelves performed better when a curved ceiling is used. In addition, uniformity was improved compared to a horizontal light shelf.

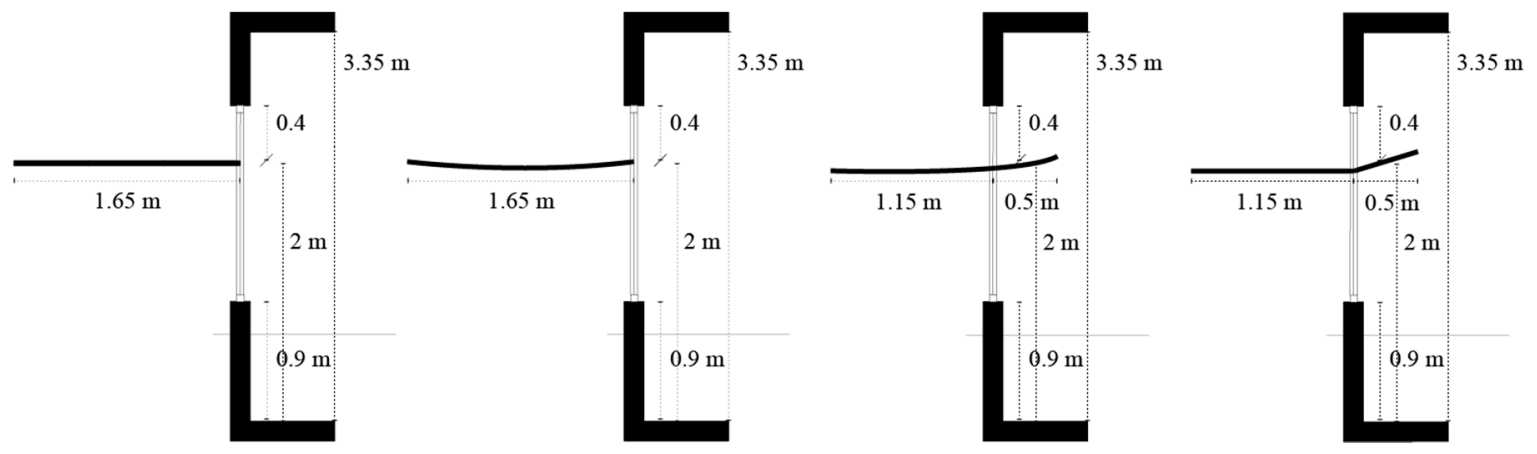

Figure 11. Light shelf designs examined in [63]. 
Xue et al. [64] examined light shelf performance in a meniscus glazing panel. It's thickness and curvature angle were the parameters studied which affected its performance. The results, after a simulation of a South oriented room in Hong Kong, China (Latitude: $22.39^{\circ} \mathrm{N}$ ) with dimensions of $10 \times 15 \mathrm{~m}$ and a ceiling height of $3 \mathrm{~m}$ with window-to-wall Ratio of $52 \%$ are as follows. The meniscus glazing panel enhances the illuminance in summer, and reduces it in winter, while the opposite happens with uniformity. An increase in illuminance is observed when the curvature angle ranges from $0^{\circ}$ to $44.3^{\circ}$ at high solar altitudes, and between $44.3^{\circ}$ and $90^{\circ}$ for low solar altitudes.

\subsection{Performance Analysis of Active Light Shelves}

In 1983, Smart and Ballinger [65] proposed a set of tracking mirrors on an equatorial mount. This arrangement was selected because the reflected beam is parallel to the right-ascension axis and collection area can be maximized. The results showed that lighting energy savings of up to $200 \mathrm{Wh} / \mathrm{m}^{2}$ day can be achieved in areas where normal beam illuminance exceeds $50,000 \mathrm{~lx}$ for at least four hours per day.

Franco [66] examined the difference between static and dynamic light shelfs (tilt angle adjustment) using simulations and scale model measurements in Sao Paulo, Brazil (Latitude: $-23^{\circ} \mathrm{S}$ ). The specific paper deals with heat gains as well, a rather rare fact in the bibliography. The north oriented scale models used had dimensions of $0.6 \times 1 \mathrm{~m}$ with a ceiling height equal to $0.6 \mathrm{~m}$ and a window-to-wall Ratio of $100 \%$. Illuminance and radiant energy measurements were collected. Two test cells were used in parallel with one of them having a static light shelf and the other a dynamic one using polished aluminum on the upper surface. In comparison with standard horizontal shading devices the heat gain using light shelves increased, but this does not seem to affect overheating conditions. Static light shelves, improve uniformity, but they decrease illuminance levels under overcast conditions. On the other hand, dynamic ones should be set in its optimum tilt in accordance with the sun's position. Otherwise, they will have a performance less than the static light shelf. Kontadakis and Tsangrassoulis $[67,68]$ assessed the daylight performance of a deep office space together with its energy balance when an active sunlight redirection system was used mounted on a light shelf (Figure 12). The results from the assessment of the system indicate the possibility of significantly improving the daylight levels of non-daylit areas ranging from $30 \%$ to $50 \%$, depending on the mirror area and on improvements in uniformity $(<40 \%)$ when compared to an unshaded/unobstructed reference case. Although lighting energy savings can be achieved, cooling consumption increases significantly, diminishing the aforementioned lighting energy savings.

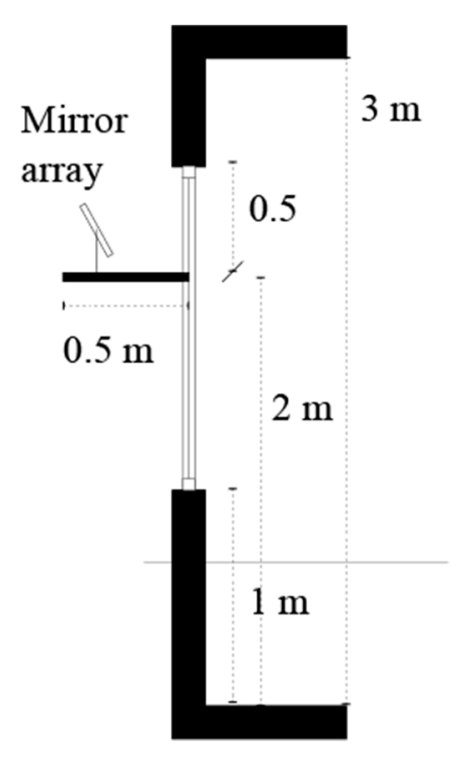

Figure 12. Schematic representation of the sunlight redirection system examined in $[68,69]$. 
Dogan and Stec [69] used a simulation approach to optimize the design of a horizontal light shelf, composed of an array of mirror tiles that can tilt on two axes tracking he sun. Five alternative designs were examined in an effort to select the most efficient variant. This consisted of a frame which holds an array of fifteen mirror tiles. Two stepper motors are used to rotate the system on two axes. The system was simulated in three locations, New York (Latitude: $40.70^{\circ}$ ), Anchorage (Latitude: $61.21^{\circ}$ ) and Phoenix (Latitude: $33.44^{\circ}$ ), using a room of dimensions $9 \times 12 \mathrm{~m}$ with a ceiling height of $3 \mathrm{~m}$. For the first two locations, a south orientation was used while for the third east-west orientations tested as well. The findings show that the dynamic light shelf did increase daylight levels resulting in an increase of estimated lighting energy savings in comparison with a mirror static shelf of $8 \%$ (Phoenix EW) to 22\% (Phoenix S).

Raphael [54] examined a light shelf with adaptive geometry. This consisted of an external part which could be rotated, and an internal part whose depth can be adjusted. Using a global optimization algorithm and radiance simulation, managed to estimate the hourly variation of the light shelf angle in an effort to minimize lighting energy consumption in an office building in Singapore (Latitude: $1.35^{\circ} \mathrm{N}$ ). Results indicate that lighting energy savings of about $12 \%$ are possible compared to a traditional static light shelf. Lim and Heng [70] extended the abovementioned study [43] by examining the daylighting performance of various internal light shelf configurations using radiance-based simulations and physical scale model experiments. Again, side by side measurements in scale models were used, one equipped with the internal light shelve configurations (Figure 13) and the other acting as a reference case.
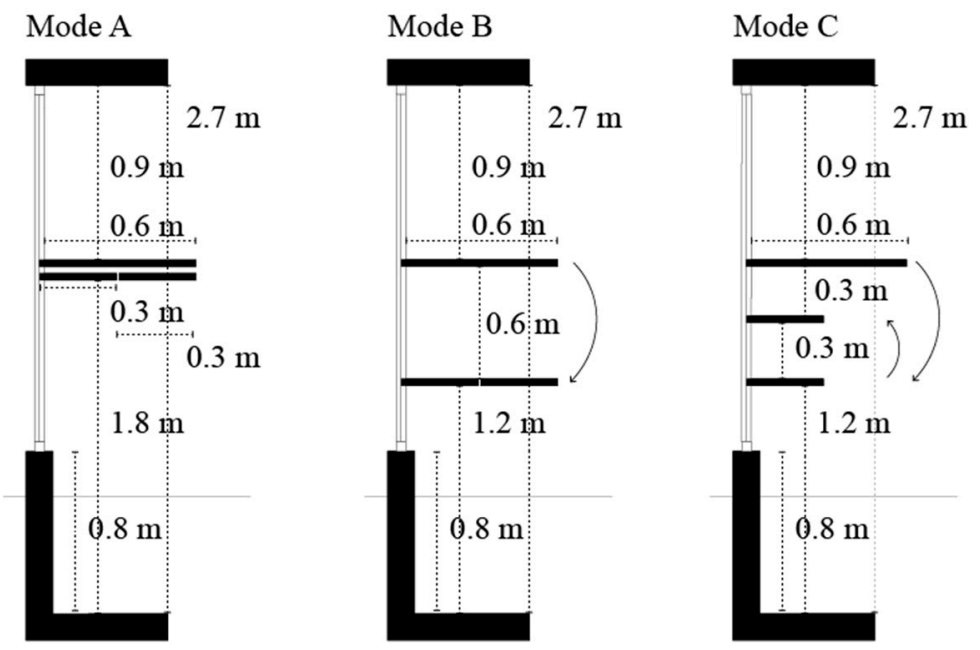

Figure 13. Schematic representation of the dynamic light shelf operation based on the optimum cases (Modes' (A-C)) proposed in [70].

The findings suggest that the height of the clerestory window plays an essential role in determining the performance of light shelves. Compared to the reference case, a decrease in illuminance values was observed, but there was a significant increase of uniformity. Light shelves with $0.9 \mathrm{~m}$ clerestory height had higher indoor illuminance than light shelves with $0.6 \mathrm{~m}$ clerestory height, but when compared the optimum cases to the base case a decrease in the percentage of DF ranging from $-62.0 \%$ to $34.1 \%$ was recorded. The optimum cases showed a significant increase in the percentage of uniformity up to $178.6 \%$. Based on the findings, the authors suggested that under clear sky conditions, the daylighting performance of a light shelf depends on the dynamic movement of solar position and proposed a dynamic light shelf control with adjustable height that responded to the optimal configurations. The authors suggested a three-step control of deployment of the shelves that could be achieved by using an illuminance sensor to measure the outdoor illuminance and if values below $20 \mathrm{~K}$ lx where measured (which was assumed to represent an overcast sky in the tropic) the first configuration could 
be employed. During an intermediate day, the dynamic internal light shelf could be programmed to configure the other two steps, based on the orientations, months and times.

Kostantoglou and Tsangrassoulis [53] examined a method of control based on the tilt angle of an exterior mirror light shelf according to the position of the sun and a predefined target area on the ceiling and analyzed the resulting lighting energy savings. Two case studies were simulated in a deep, South oriented office space with dimensions $4 \times 7 \times 2.8 \mathrm{~m}$ : (a) with static and, (b) with an automatically controlled exterior light shelf in Athens, Greece (Latitude: $37.8^{\circ}$ ).

Using the above Figure 14, the tilting angle of the light shelf $(\vartheta)$ was defined as follows:

$$
\vartheta=\left(\theta_{\text {sun }}-\omega\right) / 2
$$

where $\theta_{\text {sun }}$ is the projected sun's elevation angle, and $\omega$ a constant angle defined by the aiming point. The resulting daylight autonomy values strongly depended on window size. Using only the clerestory window (window-to-floor Ratio 6.2\%) the increase in daylight autonomy was 5 times its value of the reference case (without light-shelf) while when view window was used the aforementioned increase was only 1.15 .

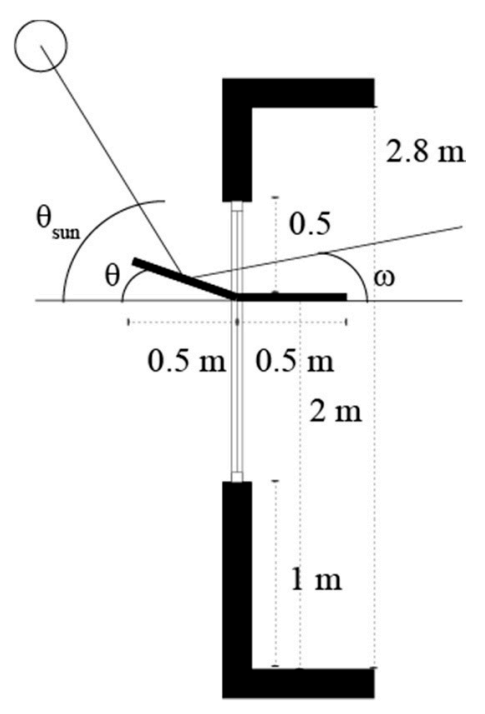

Figure 14. Tilted light shelf reflecting sunlight on a specified area on the ceiling examined in [53].

An interesting concept is the one that was proposed by Howard et al. [71]. VALRA (Variable Area Light Reflecting Assemblies) is a tracking light shelf system that reflects light into a building at the south elevation or the roof and utilizes both direct and diffuse sunlight. This configuration can perform more efficiently under all incident sun angles. Using a direct current (DC) motor, the reflective plastic film surface can be adjusted over a spring-loaded tracking roller assembly as presented in Figure 15. The effectiveness of the system is limited to a depth of about $9 \mathrm{~m}$ depending on sky conditions and mounting limits. The payback period for the VALRA was said to vary ranging from three to 20 years depending several parameters like climate, the ratio of the collection area per illuminated floor area, building type, utility rate, etc. 


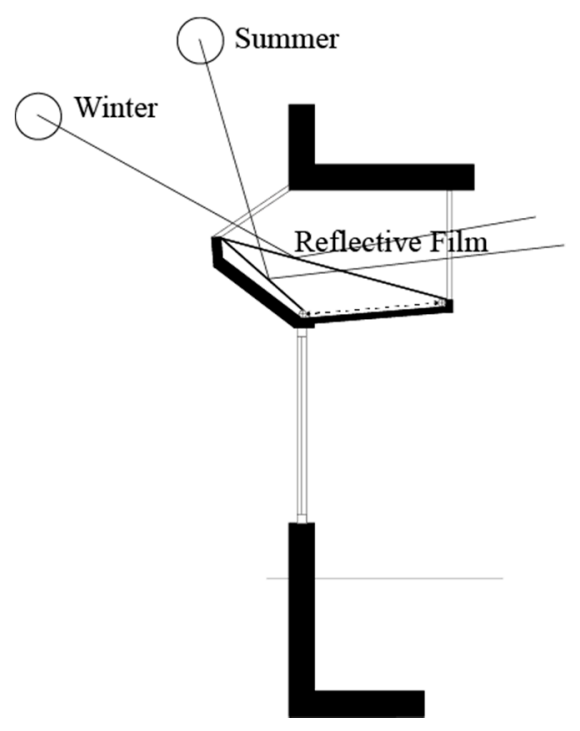

Figure 15. Operation principle of the VARLA system presented in [71].

\section{Discussion}

Daylight exploitation can increase performance and users' satisfaction of a building. However, to effectively use natural light, greater consideration is required, as every building is a unique structure and requires a different design approach. Architectural shading/daylighting systems can deliver daylight and possibly can reduce energy consumption in buildings. Is it possible to compare different light shelf designs with each other? Although the answer could be positive, in practice, such a direct comparison is problematic on the component's level. As already mentioned, most of the building standards are oriented in the performance based approach, where specific targets for the whole building are set. Consequently, the estimation of the light shelf's performance for either daylighting or energy consumption must always be performed in relation to the space in which they are placed. In practice, design teams use "rules of thumb" for the design of light shelves, an approach that can adversely affect their performance. Of course, a simulation analysis could lead to an optimal solution given that there is a budget for this. Since the light shelves are integrated into the facade, they are subject to the building code restrictions as far as their dimensions are concerned. In many cases, light shelves are actually part of the building structure, making the determination of their cost effectiveness difficult. According to our review results, there is no paper which investigates the cost optimal analysis for the light shelves. For the determination of cost-effectiveness, a life cycle analysis is needed where all costs related to the light shelf (initial, installation, operation, maintenance and disposal) are evaluated over its economic life. Conventional external flat light shelves can cost approximately $\sim 100 \$$ per $\mathrm{m}^{2}$ [72]. Depending on the geometric form of the light shelf and the finish of the upper surface, costs can vary widely. In general, light shelves are not standard products since external light shelves are designed as part of the building façade. However internal ones are today available in prefabricated modules [73-76].

This paper provides an overview of the research realized on light shelves over the last 34 years examining forty papers which address the daylight impacts of light shelves in the built environment. In the majority (92\%) of the cases reviewed, a south oriented open-plan office space having depth ranging from $5 \mathrm{~m}$ to $9 \mathrm{~m}$ was considered with ceiling heights between 2.7 and $3.5 \mathrm{~m}$ and window-to-wall Ratio between $10 \%$ and $100 \%$ under climates with high sunlight availability. In a small percentage $(18 \%)$ of the cases, there was an assessment of the light shelf performance in a full-scale mockup since computer simulations or experiments with scale models are considered as accurate and cost-effective approaches. However, the simulation results should be viewed with caution especially when a geometrically and optically complicated design is used as these require validation against scale model 
measurements. Horizontal shelves are assessed more frequently with $37 \%$ of the cases are dealt with curved forms. The majority $(82 \%)$ of the systems examined in this review were static and it seems that the analysis of their dynamic behavior is quite limited.

\section{Conclusions}

It is not easy to draw practical rules from the review since design problems involving the adoption of light shelves may differ considerably in each case. In addition, since different test room dimensions have been used in different climates, either for measurements or simulation, the comparison of the performance of various light shelf designs using existing research results is also difficult.

Nevertheless, there are some common findings:

1 Light shelves perform differently under various sky conditions. The least favorable condition is that associated with overcast sky conditions. This situation results in an overall reduction in interior daylight illuminances although a slight increase of uniformity can be achieved. However, it seems that the use of an anidolic shelf can increase the daylight factors in comparison to a reference facade with conventional double glazing. In the deeper parts of the room, this increase was 1.7 times the value of the reference case when an urban environment was simulated [61].

2 Light shelves performed best when installed in south-oriented facades.

3 Light shelves are usually placed above eye level in an effort to prevent glare form their upper surface. However, in the Collège la Vanoise in Modane, France, south window sills are used as specular light shelves having a tilt towards the south to avoid glare. Because of this tilt, the light shelf presents a seasonal selectivity to reflected sunlight.

4 Exterior light shelves can shade the lower window and if designed properly their performance can be better than conventional shading systems (i.e., overhangs) [39,46].

5 Uniformity of daylight illuminance do increase although luminance contrast can be increased giving rise to glare problems. The maximum uniformity increase that was reported is $178.6 \%$ in comparison with the reference case (i.e., window without any shading system) under clear sky conditions [63]. Under overcast conditions, uniformity is also improved but this is due to the reduction of illuminance levels in the area near the window. Another way to increase uniformity is to use an optically treated upper surface [47]. By using small mirrored surfaces oriented properly, uniformity can increase by $29.9-34.3 \%$ for the external light shelf and $10.4-13.7 \%$ for the internal, compared to the existing flat mirror-type light shelf.

6 In very broad terms, the maximum value of an external light shelf depth $\left(d_{\text {ext lightshelf,max }}\right)$ can be defined by $[33,34]$ using the equation:

$$
d_{\text {ext lightshelf,max }} \leq 1.5 \times h_{\text {clerestory }}
$$

An extreme value of two to three times the height of the clerestory window was proposed by Abdulmohsen et al. [36] when the light shelf needs to be optimized for low sun altitudes. For internal light shelves, their maximum depth value reported in the literature is again by Abdulmohsen et al. [36]. They proposed that the internal light shelf depth should be two to three times the height of the clerestory window in an effort to reduce sun patches on the working surface. However, in the majority of the cases, internal light shelf depths ranging from $0.4-1.85 \mathrm{~m}$ were examined.

7 In terms of work-plane illuminances, when a light shelf is used there is an overall decrease of illuminance values between $20 \%$ and $60 \%$ in comparison with a reference case (unshaded, no light shelf) while its effectiveness decreased after 6-7 $\mathrm{m}$ from the window. However, light shelves can increase work-plane illuminance levels in the secondary non-daylit zone ranging from $10 \%$ to over $70 \%$ when highly reflective materials or mirror surfaces are used. This relative increase is inversely proportional to the window size. $[40,45,50,53,56,59,63,67,69]$. 
8 A slight tilt of a light shelf can increase the light flux entering the room especially during summer months in the northern hemisphere, increasing at the same time the cooling load. The increase of the latitude decreases this angle [47]. In [60] Lee et al. using a light shelf that is $0.6 \mathrm{~m}$ wide with a tilt angle equal to $30^{\circ}$ upwards for buildings in Korea achieved savings for both lighting and cooling. They suggest that during winter the light shelf should be removed to save energy. It seems that the equation (4) proposed by Moore [50] give results compatible with those found by Meresi's work [51] while diverging slightly from those of Warrier and Raphael [46].

9 It seems that the shape of the ceiling can affect the distribution of illuminance. When chamfered ceiling is used, the illuminance levels increased in the rear part of the room by $21-36 \%$ and decreased by $20-55 \%$ in the front. If specular ceiling is used a further increase in illuminance levels occur $[39,52]$. Changing ceiling surface reflectance type to specular further increased illuminance levels in the back of the room was observed. In addition, the external curved and chamfered exterior light shelves performed better when a curved ceiling is used [54].

10 Dynamic control of mirrored light shelves can offer some benefits since they can redirect sunlight into a specific area on the ceiling. The results suggest that small window-to-floor ratio achieve the largest percentage increase in daylight illuminance in the deeper part of the space. Motorized designs achieved an increase in lighting energy savings in comparison with a static mirror light shelf from $8-22 \%[42,51,53,62,70]$.

As already mentioned, a light shelf is one of the simplest daylighting systems. Regardless of its ease of installation, it should be designed to suit specific demands, and this can pose a difficulty since it requires specific knowledge. Despite the research already made, there is little information on how light shelves can be best practically used. We believe that further research is needed with light shelves installed in real buildings where post-occupancy evaluations can be realized together with measurements. In a full-scale system, all possible inaccuracies of the reflective surface together with the deterioration of its reflective properties over time could be assessed. Of course, real scale testing is accurate but is also expensive and consequently simulation is used instead. This is a challenge that we need to address. The material used at a light shelf's upper surface must sustain a very high reflectance value over time. Metal mirrors are available today offering several advantages since they have the formability needed for curved light shelves together with excellent maintenance characteristics. Unfortunately, maintenance costs have not been investigated thoroughly with respect to daylighting systems literature [77]. Dirt can reduce $8-12 \%$ the reflectance of mirrors [78] and thus, a variety of coatings have been developed to improve mirror performance. For example, $\mathrm{TiO}_{2}$ coatings are used today as anti-soiling layers. This approach is considered as a preventive technique while restorative techniques are used as well (i.e., manual cleaning).

Despite the adoption of computer simulation programs, the complexity of these programs together with their limitations in simulating optically complex surfaces and/or actively controlled reflecting surfaces can be identified as weaknesses when it is required to estimate a system's performance on an hourly basis. The majority of building energy simulation tools use time series of work plane illuminance to estimate the energy savings due to the adoption of a daylight responsive lighting control system with known characteristics. This information is useful when various design alternatives are compared but it is of a limited value when a close to reality estimation of savings is required. The ceiling placed photo-sensor corresponds to incident illumination and converts it to a control signal. Selection of a sensor's proper field of view according to the geometrical characteristics of the space is quite crucial in optimizing the performance of the system. The use of a light shelf can increase the signal of the sensor due to the reflected illuminance making it difficult to accurately track the illuminance changes on the working plane. Therefore, more studies are needed on real spaces equipped with light shelf and daylight dimming systems. A decision support system (DSS) would be most welcomed by the design teams. This DSS should be based on a benchmarking process which involves estimating the performance of a specific light shelf design against a reference case. This case involves 
the use of a test room with specific dimensions. Benchmarking a design can provide insight into how well this is performing, allowing the design team to discover what characteristics need improvements.

Last but not least, all the aforementioned issues should be accompanied by a life cycle assessment to identify the types of light shelves that are environment friendly. The conclusions of this review help to identify the strengths, weaknesses, opportunities and threats of the light shelves as a daylighting/shading system. These are presented in Table 1 as a result coming from the literature analysis.

Table 1. Synoptic presentation of the strengths, weaknesses, opportunities and threats of the light shelves as a daylighting/shading system.

\begin{tabular}{|c|c|}
\hline Strengths & Weaknesses \\
\hline $\begin{array}{l}\text { - Indoor lighting environment improvement. } \\
\text { - } \quad \text { Productivity, well-being and mood improvement. } \\
\text { - } \quad \text { Lightininance uniformity improvement. } \\
\text { - } \quad \text { Ease of installation. } \\
\text { - Well-accepted by architectural community. }\end{array}$ & 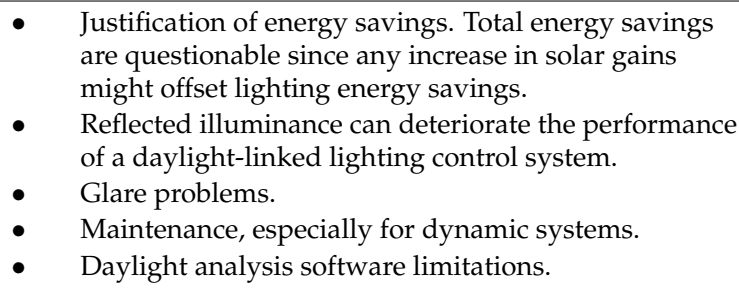 \\
\hline Opportunities & Threats \\
\hline 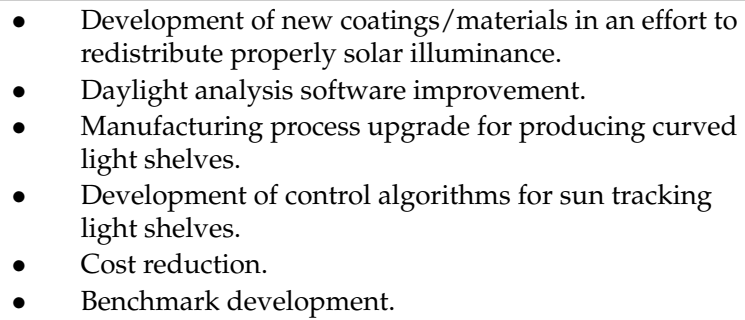 & $\begin{array}{l}\text { Manufacturing of curved highly reflecting surfaces } \\
\text { might be difficult. Any intolerance might adversely } \\
\text { affect user acceptance. } \\
\text { There is a lack of the expertise needed for advanced } \\
\text { light shelf design since current design methodologies } \\
\text { are quite complicated for the design teams. } \\
\text { Cost effectiveness. }\end{array}$ \\
\hline
\end{tabular}

Figure 16 presents the annual number of papers reviewed from 1983 till today. It seems that in the last two years there has been a substantial increase in this number. We believe that the reason for this increase is the effort to achieve cost efficient solutions in order to exploit daylight, and, of course, the improvements in the daylight simulation software.

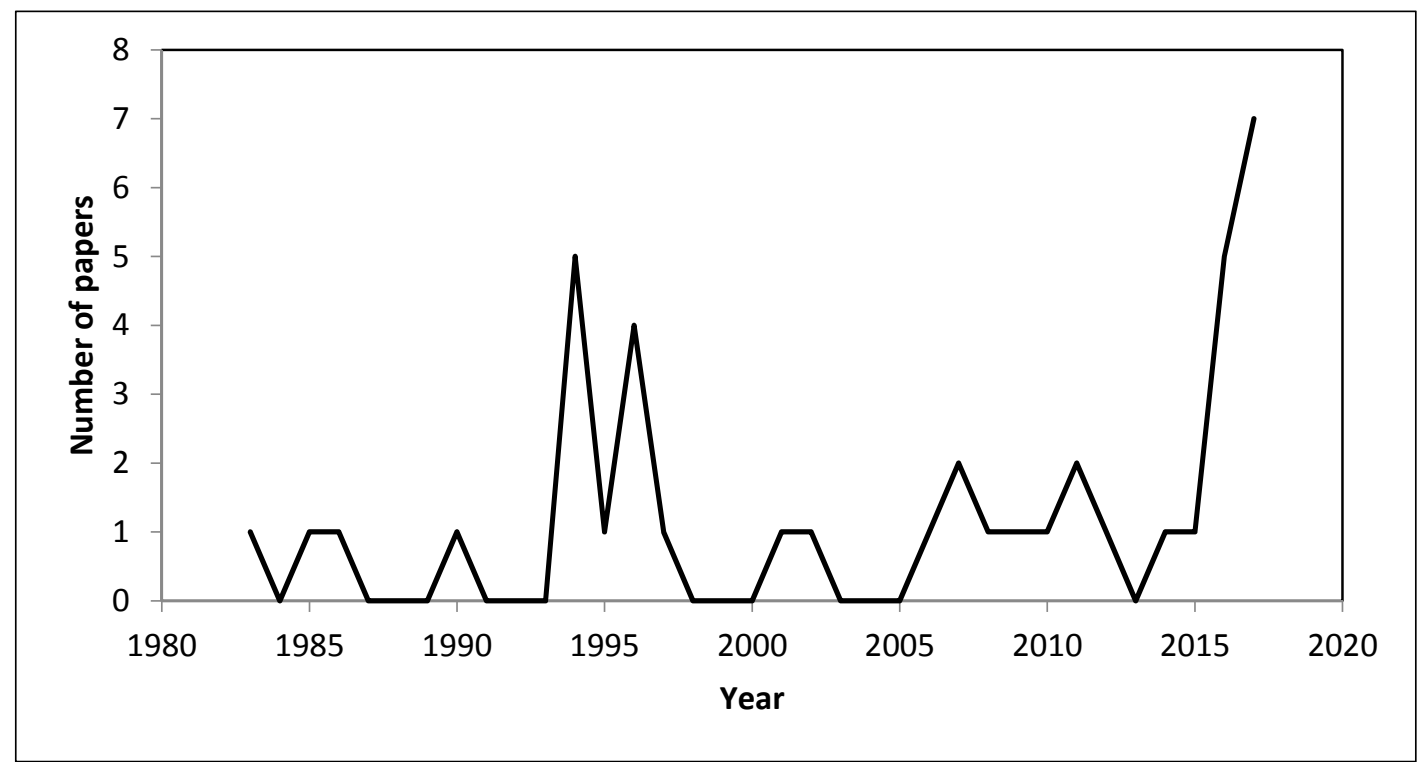

Figure 16. Annual number of papers dealing with the impact of light shelves on the illuminance in buildings. 
The main results of this work point out that there is research that needs to be realized in order to improve the performance of light shelves. It seems that there are several opportunities in relation to new materials, new geometries and dynamic operation of the light shelves, defining the future research focus.

Acknowledgments: This study was funded by the "Research projects for excellence IKY/SIEMENS".

Author Contributions: Antonis Kontadakis and Aris Tsangrassoulis are the main contributors to this paper Lambros Doulos and Stelios Zerefos made substantial contribution to the research work and the SWOT method.

Conflicts of Interest: The founding sponsors had no role in the design of the study; in the collection, analyses, or interpretation of data; in the writing of the manuscript, and in the decision to publish the results.

\section{References}

1. Lockley, S.W. Influence of Light on Circadian Rhythmicity in Humans. In Encyclopedia of Neuroscience; Elsevier: Oxford, UK, 2008.

2. Boyce, P.R.; Hunter, C.; Howlett, H. The Benefits of Daylight through Windows; Lighting Research Center: New York, NY, USA, 2003.

3. Rashid, M.; Zimring, C. A Review of the Empirical Literature on the Relationships between Indoor Environment and Stress in Health Care and Office Settings: Problems and Prospects of Sharing Evidence. Environ. Behav. 2008, 40, 151-173. [CrossRef]

4. Edwards, L.; Torcellini, P. A Literature Review of the Effects of Natural Light on Building Occupants; National Renewable Energy Laboratory: Golden, CO, USA, 2002.

5. Galasiu, A.D.; Veitch, J.A. Occupant Preferences and Satisfaction with the Luminous Environment and Control Systems in Daylit Offices: A Literature Review. Energy Build. 2006, 38, 728-742. [CrossRef]

6. Gago, E.J; Muneer, T.; Knez, M.; Köster, H. Natural Light Controls and Guides in Buildings. Energy Saving for Electrical Lighting, Reduction of Cooling Load. Renew. Sustain. Energy Rev. 2015, 41, 1-13. [CrossRef]

7. Doulos, L.; Tsangrassoulis, A.; Topalis, F.V. Multi-criteria decision analysis to select the optimum position and proper field of view of a photosensor. Energy Convers. Manag. 2014, 86, 1069-1077. [CrossRef]

8. Doulos, L.T.; Tsangrassoulis, A.; Kontaxis, P.A.; Kontadakis, A.; Topalis, F.V. Harvesting daylight with LED or T5 fluorescent lamps? The role of dimming. Energy Build. 2017, 140, 336-347. [CrossRef]

9. Doulos, L.; Tsangrassoulis, A.; Topalis, F. Quantifying energy savings in daylight responsive systems: The role of dimming electronic ballasts. Energy Build. 2008, 40, 36-50. [CrossRef]

10. Lee, H.; Kim, S.; Seo, J. Evaluation of a light shelf based on energy consumption for lighting and air conditioning. Indoor Built Environ. 2017. [CrossRef]

11. Reinhart, C.F. A Simulation Based Review on the Ubiquitous Window Head Height to Daylit Zone Depth Rule of Thumb. In Proceedings of the 9th International IBPSA Conference, Montréal, QC, Canada, 15-18 August 2005.

12. EN 15193-1: Energy Performance of Buildings. Energy Requirements for Lighting. 2017. Available online: https:/ / shop.bsigroup.com/ProductDetail?pid=000000000030292858 (accessed on 5 November 2017).

13. Reinhart, C.F; LoVerso, V.R.M. A rules of thumb-based design sequence for diffuse daylight. Light. Res. Technol. 2010, 42, 7-31. [CrossRef]

14. Kontadakis, A.; Tsangrassoulis, A.; Roetzel, A. Defining the Boundaries of Daylight Penetration. The use of dynamic and static daylight methods to predict the daylit zone within sidelit spaces, a comparison. In Proceedings of the BalkanLight 2015, the 6th Balkan Conference on Lighting, Athens, Greece, 16-19 September 2015.

15. Konstantoglou, M.; Tsangrassoulis, A. Dynamic operation of daylighting and shading systems: A literature review. Renew. Sustain. Energy Rev. 2016, 60, 268-283. [CrossRef]

16. Bellia, L.; Marino, C.; Minichiello, F.; Pedace, A. An Overview on Solar Shading Systems for Buildings. Energy Procedia 2017, 62, 309-317. [CrossRef]

17. Aschehoug, O.; Christoffersen, J.; Jakobiak, R.; Johnsen, K.; Lee, E.; Ruck, N.; Selkowitz, S. Daylight in Buildings: A Source Book on Daylighting Systems and Components; Report of IEA SHC Task 21/ECBCS Annex 29; Lawrence Berkeley National Laboratory: Berkeley, CA, USA, 2000. Available online: https:/ / facades.lbl. gov/publications/daylight-buildings-source-book-daylighting-systems (accessed on 5 November 2017). 
18. Mayhoub, M.S. Innovative daylighting systems' challenges: A critical study. Energy Build. 2014, 80, $394-405$. [CrossRef]

19. Aizlewood, M.E. Innovative daylighting systems: An experimental evaluation. Int. J. Light. Res. Technol. 1993, 25, 141-152. [CrossRef]

20. Littlefair, P.J. Developments in Innovative Daylighting; IHS BRE Press: Bracknell, UK, 2000.

21. Littlefair, P.J. Innovative daylighting: Review of systems and evaluation methods. Light. Res. Technol. 1990, 22, 1-17. [CrossRef]

22. Wong, I.L. A review of daylighting design and implementation in buildings. Renew. Sustain. Energy Rev. 2017, 74, 959-968. [CrossRef]

23. Illuminating Engineering Society of North America (IESNA). Recommended Practice of Daylighting, RP-5, 1978. In IES Lighting Handbook; IESNA: New York, NY, USA, 2000.

24. Kischkoweit-Lopin, M. An overview of daylighting systems. Sol. Energy 2002, 73, 77-82. [CrossRef]

25. Littlefair, P.J.; Aizlewood, M.E.; Birtles, A.B. The performance of innovative daylighting systems. Renew. Energy 1994, 5, 920-934. [CrossRef]

26. Freewan, A.A. Developing daylight devices matrix with special integration with building design process. Sustain. Cities Soc. 2015, 15, 144-152. [CrossRef]

27. Nair, M.; Ramamurthy, K.; Ganesan, A. Classification of indoor daylight enhancement systems. Light. Res. Technol. 2014, 46, 245-267. [CrossRef]

28. Mayhoub, M.; Carter, D. Hybrid lighting systems: Performance and design. Light. Res. Technol. 2012, 44, 261-276. [CrossRef]

29. Wassim, J.; Potamianos, I. Geometry, Light, and Cosmology in the Church of Hagia Sophia. Int. J. Archit. Comput. 2007, 5, 304-319.

30. Potamianos, I. Light into Architecture: The Evocative Use of Natural Light as Related to Liturgy in Byzantine Churches. Ph.D. Thesis, University of Michigan, Ann Arbor, MI, USA, 1996.

31. Tageslichtreflector. Available online: https://commons.wikimedia.org/wiki/File:L-Tageslichtreflector.png (accessed on 5 November 2017).

32. Hopkinson, R.G. Daylighting a hospital ward. Archit. J. 1952, 115, 255-259.

33. Selkowitz, S.; Navvab, M.; Mathews, S. Design and Performance of Light Shelves. In Proceedings of the International Daylighting Conference, Phoenix, AZ, USA, 16-18 February 1983.

34. Place, W.; Howard, T.C. Daylighting Multistory Office Buildings; North Carolina Alternative Energy Corporation: Raleigh, NC, USA, 1990.

35. Littlefair, P.J. Light shelves: Computer assessment of daylighting performance. Light. Res. Technol. 1995, 27, 79-91. [CrossRef]

36. Abdulmohsen, A.; Boyer, L.; Degelman, L. Evaluation of lightshelf daylighting systems for office buildings in hot climates. In Proceedings of the Ninth Symposium on Improving Building Systems in Hot and Humid Climates, Arlington, TX, USA, 19-20 May 1994.

37. Soler, A.; Oteiza, P. Dependence on solar elevation of the performance of a light shelf as a potential daylighting device. Renew. Energy 1996, 8, 198-201. [CrossRef]

38. Soler, A.; Oteiza, P. Light Shelf performance in Madrid Spain. Build. Environ. 1997, 22, 87-93. [CrossRef]

39. Claros, S.T.; Soler, A. Indoor daylight climate-comparison between light shelves and overhang performances in Madrid for hours with unit sunshine fraction and realistic values of model reflectance. Sol. Energy 2001, 71, 233-239. [CrossRef]

40. Berardi, U.; Anaraki, H.K. The benefits of light shelves over the daylight illuminance in office buildings in Toronto. Indoor Build Environ. 2016, 1-19. [CrossRef]

41. Ochoa, C.E.; Capeluto, I.G. Evaluating visual comfort and performance of three natural lighting systems for deep office buildings in highly luminous climates. Build. Environ. 2006, 41, 1128-1135. [CrossRef]

42. Joarder, M.A.R.; Ahmed, Z.N.; Price, A.; Mourshed, M. A simulation assessment of the height of light shelves to enhance daylighting quality in tropical office buildings under overcast sky conditions in Dhaka, Bangladesh. In Proceedings of the 11th International IBPSA Conference, Glasgow, UK, 27-30 July 2009.

43. Hu, J.; Du, J.; Place, W. The Assessment of Advanced Daylighting Systems in Multi-Story Office Buildings Using a Dynamic Method. In Proceedings of the World Renewable Energy Congress, Low Energy Architecture (LEA), Linkoping, Sweden, 8-13 May 2011. 
44. Lim, Y.; Ahmad, M.H. The effects of direct sunlight on light shelf performance under tropical sky. Indoor Built Environ. 2015, 24, 788-802. [CrossRef]

45. Kurtay, C.; Esen, O. A new method for light shelf design according to latitudes: CUN-OKAY light shelf curves. J. Build. Eng. 2017, 10, 140-148. [CrossRef]

46. Warrier, G.A.; Raphael, B. Performance evaluation of light shelves. Energy Build. 2017, 140, 19-27. [CrossRef]

47. Lee, H.; Jeon, G.; Seo, J.; Kim, Y. Daylighting performance improvement of a light-shelf using diffused reflection. Indoor Build Environ. 2017, 26, 717-726. [CrossRef]

48. Moscoso, C.; Matusiak, B. Aesthetic perception of a small office with different daylighting systems. Indoor Built Environ. 2017. [CrossRef]

49. Moazzeni, M.H.; Ghiabaklou, Z. Investigating the Influence of Light Shelf Geometry Parameters on Daylight Performance and Visual Comfort, a Case Study of Educational Space in Tehran, Iran. Buildings 2016, 6, 26. [CrossRef]

50. Moore, F. Concepts and Practice of Architectural Daylighting; Van Nostrand Reinhold Company: New York, NY, USA, 1985.

51. Meresi, A. Evaluating daylight performance of light shelves combined with external blinds in south-facing classrooms in Athens, Greece. Energy Build. 2016, 116, 190-205. [CrossRef]

52. Al-Sallal, K.A. Testing glare in universal space design studios in Al-Ain, UAE desert climate and proposed Improvements. Renew. Energy 2007, 32, 1033-1044. [CrossRef]

53. Kostantoglou, M.; Tsangrassoulis, A. Performance evaluation of an automatically controlled light-shelf. In Proceedings of the 5th Balkan Light Conference, Belgrad, Serbia, 3-6 October 2012.

54. Raphael, B. Active Control of Daylighting Features in Buildings. Comput. Aided Civ. Infrastruct. Eng. 2011, 26, 393-405. [CrossRef]

55. Lee, E.S.; Beltrán, L.O.; Selkowitz, S.E. Demonstration of a Light-redirecting Skylight system at the Palm Springs Chamber of Commerce. Presented at the ACEEE 1994 Summer Study on Energy Efficiency in Buildings, Building Tomorrow: The Path to Energy Efficiency, Pacific Grove, CA, USA, 28 August-3 September 1994.

56. Beltran, L.O.; Lee, E.S.; Selkowitz, S.E. Advanced Optical Daylighting Systems. In Proceedings of the IESNA Annual Conference, Cleveland, OH, USA, 4-7 August 1996.

57. Beltran, L.O.; Lee, E.S.; Papamichael, K.M.; Selkowitz, S.E. The Design and Evaluation of Three Advanced Daylighting Systems: Light Shelves, Light Pipes, and Skylights. In Proceedings of the ASES 19th National Passive Solar Conference, San Jose, CA, USA, 25-30 June 1994.

58. Lee, E.S.; Selkowitz, S.E.; Rubinstein, F.M.; Klems, J.H.; Beltrán, L.O.; DiBartolomeo, D.L. A Comprehensive Approach to Integrated Envelope and Lighting Systems for New Commercial Buildings; Report Number: LBL-35732; Lawrence Berkeley National Laboratory: Berkeley, CA, USA, 1994.

59. Lee, E.S.; Beltrán, L.O.; Selkowitz, S.E. Demonstration of a Light-redirecting Skylight system at the Palm Springs Chamber of Commerce. Presented at the 1996 ACEEE Summer Study on Energy Efficiency in Buildings: Profiting from Energy Efficiency, Pacific Grove, CA, USA, 25-31 August 1996.

60. Lee, H.; Kim, K.; Seo, J.; Kim, Y. Effectiveness of a perforated light shelf for energy saving. Energy Build. 2017, 144, 144-151. [CrossRef]

61. Scartezzini, J.L.; Gouret, G. Anidolic daylighting systems. Sol. Energy 2002, 73, 123-135. [CrossRef]

62. Freewan, A.A.; Shao, L.; Riffat, S. Optimizing performance of the lightshelf by modifying ceiling geometry in highly luminous climates. Sol. Energy 2008, 82, 343-353. [CrossRef]

63. Freewan, A.A. Maximizing the lightshelf performance by interaction between lightshelf geometries and a curved ceiling. Energy Convers. Manag. 2010, 51, 1600-1604. [CrossRef]

64. Xue, P.; Mak, C.M.; Cheung, H.D. New static lightshelf system design of clerestory windows for Hong Kong. Build. Environ. 2014, 72, 368-376. [CrossRef]

65. Smart, M.; Ballinger, J.A. Tracking Mirror Beam Sunlighting for Deep Interior Spaces. Sol. Energy 1983, 30, 527-536. [CrossRef]

66. Franco, I.M. Efficacy of light shelves: Passive, dynamic and automatic devices related to light and thermal behavior. Presented at the Thermal Performance of Exterior Envelopes of Whole Buildings X, Clearwater Beach, FL, USA, 2-7 December 2007.

67. Kontadakis, A.; Tsangrassoulis, A. The impacts of a dynamic sunlight redirection system on the energy balance of office buildings. In Proceedings of the CISBAT 2017 International Conference—Future Buildings \& Districts—Energy Efficiency from Nano to Urban Scale, Lausanne, Switzerland, 6-8 September 2017. 
68. Kontadakis, A.; Tsangrassoulis, A.; Doulos, L.; Topalis, F. An active sunlight redirection system for daylight enhancement beyond the perimeter zone. Build. Environ. 2017, 113, 267-279. [CrossRef]

69. Dogan, T.; Stec, P. Prototyping a façade-mounted, dynamic, dual-axis daylight redirection system. Light. Res. Technol. 2016, 1-13. [CrossRef]

70. Lim, Y.W.; Heng, C.Y.S. Dynamic Internal Light Shelf for Tropical Daylighting in High-rise Office Buildings. Build. Environ. 2016, 106, 155-166. [CrossRef]

71. Howard, T.C.; Place, W.; Andersson, B.; Coutiers, P. Variable area light reflecting assemblies (VALRA). In Proceedings of the 2nd International Daylighting Conference, Long Beach, CA, USA, 4-7 November 1986; pp. 222-234.

72. Wulfinghoff, R.W. Energy Efficiency Manual; Energy Institute Press: Wheaton, MD, USA, 1999; ISBN 978-0-9657926-7-7.

73. InLighten Interior Light Shelf. Available online: http://www.kawneer.com/kawneer/north_america/en/ product.asp?prod_id=1852\&desc=aluminum-curtain-wall-light-shelves (accessed on 5 November 2017).

74. BrightShelf. Available online: http://brightshelf.com/index.html (accessed on 5 November 2017).

75. aLuminate ${ }^{\mathrm{TM}}$ Light Shelves. Available online: https://www.tubeliteinc.com/aluminate-light-shelves/ (accessed on 5 November 2017).

76. Luminance Light Shelf System. Available online: https://www.ykkap.com/commercial/product/suncontrol/luminance/ (accessed on 5 November 2017).

77. Mayhoub, M. Cleaning innovative daylighting systems: Economic assessment. Energy Build. 2017, 153, 63-71. [CrossRef]

78. Atkinson, C.; Sansom, C.L.; Almond, H.J.; Shaw, C.P. Coatings for concentrating solar systems-A review. Renew. Sustain. Energy Rev. 2015, 45, 113-122. [CrossRef]

(C) 2017 by the authors. Licensee MDPI, Basel, Switzerland. This article is an open access article distributed under the terms and conditions of the Creative Commons Attribution (CC BY) license (http:// creativecommons.org/licenses/by/4.0/). 